\title{
A TÁPLÁLKOZÁS ÉS A CIVILIZÁCIÓS BETEGSÉGEK KAPCSOLATA
}

\author{
Panyor Ágota
}

\begin{abstract}
Absztrakt: Az egészséges életmód két kiemelten fontos pillére az egészségtudatos táplálkozás és a rendszeres testmozgás. Az egészséges táplálkozás hozzájárul az általános jóléthez és számos krónikus betegség megelőzésének alapja. A táplálkozással összefüggő civilizációs betegségek világméretü problémák. Ennek csökkentéséhez egyre inkább tudatosítani kell az emberekben a megváltozott körülmények emberi szervezetre gyakorolt kedvezőtlen hatásait és az életmódbeli változásokra fel kell hívni a figyelmet.
\end{abstract}

\begin{abstract}
The two important pillars of a healthy lifestyle health conscious eating and regular physical exercise. Healthy eating contributes to overall well-being and the basis for the prevention of many chronic diseases. Nutrition-related civilization diseases are global problems. People need to be made more aware of this to reduce this changed life and environment unfavourable impact for human body and pay attention to lifestyle changes.
\end{abstract}

Kulcsszavak: civilizációs betegségek, elhízás, egészséges táplálkozás, funkcionális élelmiszerek

Keywords: civilization diseases, overweight, healthy eating, functional foods

\section{Bevezetés}

Napjaink világméretü problémája a civilizációs betegségek drasztikus emelkedése, melyeknek jelentős része összefüggésbe hozható a helytelen táplálkozási szokásokkal. Európában a vezető halálok a szív-és érrendszeri megbetegedések és a daganatok. Ezen halálokok legfontosabb kockázati tényezői szoros kapcsolatban vannak a mindennapi táplálkozással. A legnagyobb problémákat a magas vérnyomás, a magas koleszterinszint, az elhízás, a túlzott alkoholfogyasztás jelenti.

Európában a születéskor várható élettartam 79,2 év. Általánosságban, az EU lakosainak utolsó 15 életévében valamilyen megbetegedés csökkenti az életminőséget. Magyarországon mind a születéskor várható élettartam, mind az egészségben eltöltött életévek száma jelentősen elmarad az EU átlagtól. A magyar férfiak születéskor várható átlagos élettartama 71,6 év (az EU 15 átlagától 7,6 évvel maradunk el). A magyar nők átlagosan 78,7 évig élnek, vagyis 4,7 évvel kevesebb ideig, mint az EU 15 tagországainak női lakosai (Szakály, 2011).

Magyarországon az elhízás, a daganatok, valamint a szív-és érrendszeri megbetegedések előfordulása kiemelkedően magas. Az elhízás mértékétől függően nő a szív-és érrendszeri betegségek, a hipertónia, a 2-es típusú diabetes, egyes anyagcsere-zavarok, néhány daganatos betegség, a krónikus mozgásszervi betegségek, bizonyos mentális kórképek és az összhalálozás kockázata.

Az egészséges táplálkozás és a rendszeres testmozgás az egészséges életmód két kiemelten fontos pillére. Az egészséges táplálkozás kialakításához a különféle élelmiszereket és folyadékokat megfelelő arányban, mennyiségben és változatosan kell fogyasztani. A táplálkozás az egészség megőrzésében kiemelten fontos szerepet játszik. Az egészséges táplálkozás hozzájárul az általános jólléthez és számos krónikus betegség megelőzésének alapja. Az egészséges táplálkozás 
kiegyensúlyozott és változatos étrendet jelent, melynek jellemző összetevői a friss és természetes ételek, sok gyümölcs és zöldség, valamint vitaminokat és ásványi anyagokat tartalmazó élelmiszerek (Povey et.al.,1998).

A WHO jelentése szerint is a táplálkozási tényezők meghatározó faktorai az egészségnek és a jólétnek. A legfontosabb táplálkozási kockázati tényezőket az alábbiakban foglalja össze: magas energia,- telített zsírsav-, transz-zsírsav-, hozzáadott cukor- és sóbevitel, illetve elégtelen zöldség-és gyümölcs-, valamint élelmi rostfogyasztás (www.euro.who.int).

\section{Táplálkozással összefüggő betegségek}

Az elmúlt időszakban megjelenő kényelmi trendek a feldolgozott élelmiszerek erőteljes növekedését eredményezték, amelyek jelentős mértékben a táplálkozási szokásokra is hatást gyakorolnak. Az energiaegyensúly felbomlása maga után vonta a cukorbetegség, a szív -és érrendszeri megbetegedések, valamint egyes daganatos betegségek egyre nagyobb arányú előfordulását. A kényelmes, ülő életmód elterjedésével csökken az emberek energiafelhasználása, ugyanakkor egyre nagyobb adagokat fogyasztanak, akár napi átlagban 200-400 kcal-val többet, mint 20 évvel ezelött.

Fontos figyelni az étrendünk zsírtartalmára és zsírsav-összetételére, valamint a megfelelő élelmirost bevitelre. Ma már nem feltevés, hanem tény, hogy egészségünknek, életünknek fontos meghatározója a táplálkozás. Az étrend és az életmód befolyással van a legtöbb betegség kialakulására, amelyek megelőzhetőek lennének megfelelő táplálkozással, életvitellel (Antal, 2007). Kiemelt figyelemmel kell lenni a testtömeg-csökkentés során a jó biológiai értékü fehérjebevitelre is, amelynek a napi mértéke $1 \mathrm{~g} /$ testtömeg kg-volumen. A szénhidrátbevitel csökkentése ajánlott, mindenekelőtt a cukorfogyasztás mérséklése formájában. A zsiradékbevitel során az állati eredetủ zsiradékok bevitelének csökkentését ajánlják a szakemberek. A napi elemi rost bevitel mennyisége 30-40 g/nap, emellett a bőséges folyadékbevitelre kiemelt figyelmet szükséges szentelni. Fontos a szervezet vitaminés ásványi anyag szükségletének biztosítása is (Balogh, 2017).

\subsection{Elhízás, mint népbetegség}

A civilizációs betegségek közül kiemelkedő az elhízás, amely számos egészségügyi probléma önálló rizikófaktora. Ideértve a magas vérnyomást, a magas koleszterinszintet, a cukorbetegséget, a szív-és érrendszeri megbetegedéseket és a daganatos betegségek néhány fajtáját. Az elhízás járványszerü méreteket ölt világszerte, több mint 1 milliárd ember szenved a túlsúlyos állapottól. Az 1. ábra adatai alapján láthatóak a világ egyes országaiban az elhízottak illetve túlsúlyosak aránya.

$\mathrm{Az}$ egészségtelen életmód, az átalakuló táplálkozás (benne az energiában gazdag, de tápanyagban szegény élelmiszer-fogyasztás) párosulva a fizikai aktivitás hiányával, oda vezetett, hogy az elhízás egyes földrészeken háromszor-négyszer olyan gyakori, mint amilyen 1980-ban volt (Popkin, 2009). Az Európai Unió felnőtt lakosságának is több mint fele elhízott, amely folyamatosan növekvő tendenciát 
mutat. Előrejelzések szerint 2030-ra meg fog duplázódni az elhízás mértéke az európai felnőtt lakosság körében a 2000-ben mért értékhez képest. Sajnos ezen belül a legfiatalabb korosztályok esetében is rendkívül magas a gyermek-és serdülőkori obezitás világviszonylatban.

Az elhízás hosszú távú növekedéséhez számos környezeti és magatartásbeli tényezö is hozzájárul föleg az iparosodott városokban, úgy, mint az energiában gazdag ételek széleskörü elérhetősége, az adagnagyság növekedése, valamint a fizikailag inaktívan töltött növekvő idő. Az urbanizáció miatt egyre több ember étrendjében dominálnak a feldolgozott ételek, és globálisan is nézve egyre több olyan étel kerül az emberek tányérjára, amely valamiféle fizikai és kémiai eljáráson esett át.

Sajnálatos módon az elhízás előfordulása az EU-n belül Magyarországon az egyik legmagasabb (www.ec.europe.eu). A felnőtt magyar lakosság közel kétharmada (62\%) testtömeg index (BMI) alapján túlsúlyos vagy elhízott. A túlsúly és az elhízás gyakorisága minkét nemnél nő az életkorral. A 18-34 éves korú fiatal férfiak $41 \%$-ának magasabb a testtömeg indexe 25-nél, a 65 feletti korcsoportban ez az arány már $76 \%$. A fiatal nőknél a túlsúly és az elhízás együttes előfordulása $30 \%$, alacsonyabb, mint a hasonló korú férfiaknál, ugyanakkor idős korra ez az arány a nőknél 83\%-ra nö, meghaladva a férfiakét. Férfiaknál az elhízottak aránya 63\%, ami több mint kétszerese az utolsó hasonló vizsgálat (1985-1988) adataihoz képest. Nöknél szintén 50\%-os növekedés tapasztalható a mért értékek alapján (www.oeti.hu). Ezek az adatok azért is megdöbbentőek, mert az elhízás mértékétől függően nő a szív-és érrendszeri betegségek, a hipertónia, a 2-es típusú diabetes, az egyes anyagcsere-zavarok, bizonyos daganatos betegségek és az összhalálozás kockázata is. 


\section{1. ábra: Az elhízottak aránya a világ egyes országaiban}

Figure 1: Obesity among adults, 2015 or nearest year
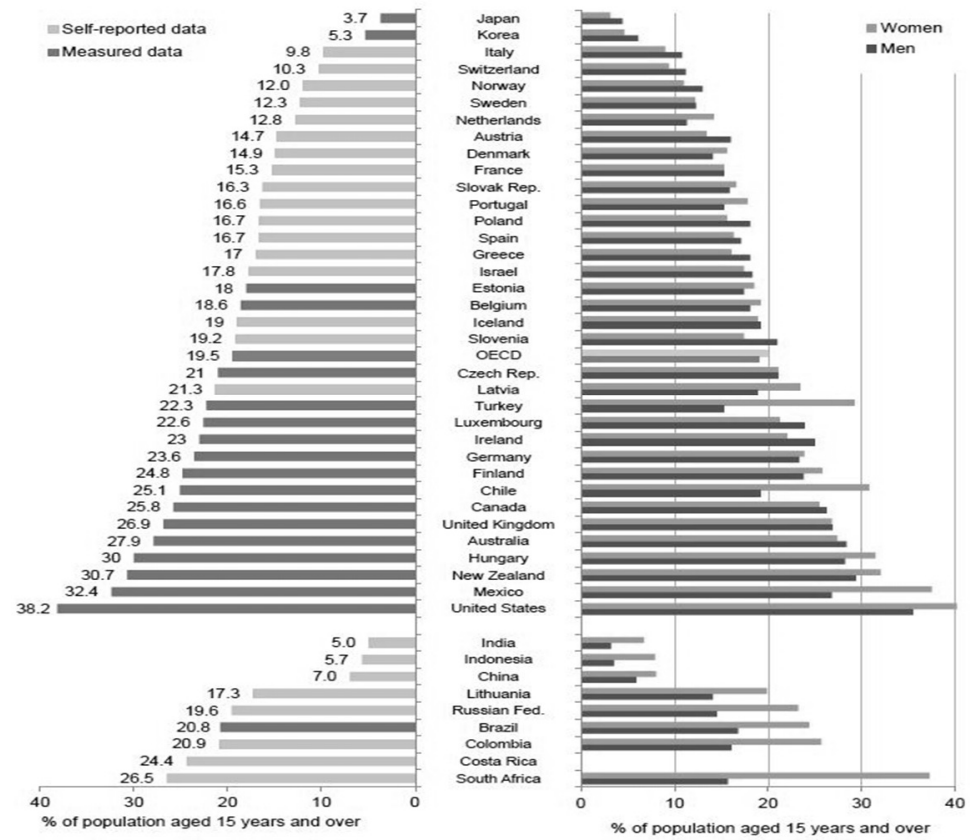

Forrás: www.ec.europe.eu

\subsection{Cukorbetegség}

A WHO adatai szerint 2000-ben a világon 171 millió cukorbeteget regisztráltak, 2030-ra várhatóan ez a szám eléri a 366 milliót. A drasztikus növekedés elsősorban a fejlett országokban fog bekövetkezni, ami a népesség növekedésének, korosodásának, egészségtelen táplálkozásának, az elhízásnak és az ülő életmódnak köszönhetö. A cukorbetegségnek tulajdonított halálozások száma évente 3,2 millió, emellett a diabétesz az idő előtti megbetegedések és mortalitás egyik fö rizikótényezőjévé vált, föként a szív-ér rendszeri betegségek megnövekedett kockázata miatt. A cukorbetegség kialakulása elleni, elsődleges védekezés a helyes étrend összeállítása és a rendszeres testmozgás (Puska, Waxman és Porter, 2003).

Hazánkban a cukorbetegségben szenvedők száma enyhe becslések alapján is 700-800 ezer körülire tehető, ám az észrevétlen eseteket is figyelembe véve akár az 1 millió foót is meghaladhatja ez a szám (2. ábra). Jobban kellene foglalkoznunk a táplálkozásunk milyenségével, hiszen az egyes becslések világosan mutatják, hogy a legtöbb áldozattal járó krónikus betegségek 70-80 százaléka összefüggésben áll valamilyen módon az egészségtelen étrenddel (Szücs, 2016).

A cukorbetegséggel több súlyos betegség, komplikáció és szövődmény is együtt jár. A betegek mintegy 50-80\%-ának halálát szív-ér rendszeri betegségek okozzák, s ezek kialakulását szinte minden esetben magas vérnyomás és elhízás kíséri (Després, 2001). A széles körben elfogadott szakmai álláspont szerint a hazai teljes lakosság 5-6\%-a szenved ismert módon cukorbetegségben. Problémát okoz a pontos arányok 
megállapításakor, hogy a cukorbetegség előfordulása az életkor előrehaladtával növekszik, így a 60-65 év feletti lakosságréteg esetében a 12-15\%-os aránnyal is számolhatunk. Ez azt jelenti, hogy a magasabb életkorú felnőttek között minden hatodik-nyolcadik ember cukorbetegségben szenved. Fontos látnunk, hogy a helyes táplálkozással, csökkentettebb energiabevitellel és magasabb gyümölcs- és zöldségfogyasztással valamint a mozgásmennyiség növelésével jelentősen csökkenthető a cukorbetegség.

\section{2. ábra: Cukorbetegek számának alakulása Magyarországon 1999 és 2015 között}

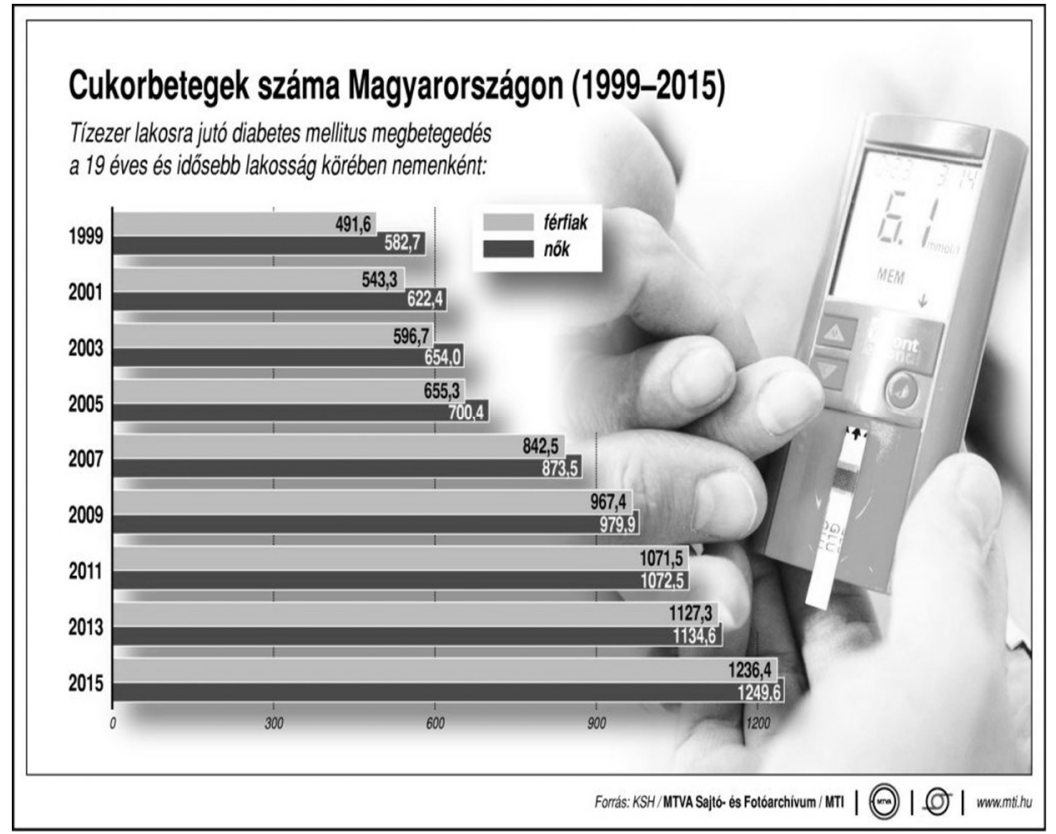

Forrás: www.24.hu

\subsection{Keringési rendszer betegségei}

A szív- és érrendszeri megbetegedések és az általuk okozott halálozás legfontosabb kockázati tényezői: a magasvérnyomás-betegség, a cukorbetegség, a zsíranyagcsere betegség, az elhízás, a dohányzás és az alkoholizmus, valamint az egészségtelen táplálkozás, a mozgásszegény életmód (Soós et. al., 2015).

Mózsik és szerzőtársai (2001) megállapították, hogy a magasvérnyomásbetegségben szenvedőknél három-négyszer nagyobb arányban alakulnak ki szívbetegségek, és kb. hétszer gyakrabban fejlödik ki központi idegrendszeri károsodás, stroke. Magyarországon a keringési betegségek közül az iszkémiás szívbetegség és az agyérbetegség okozta halálozás 3-4-szerese az EU15 országokban tapasztaltaknak (NEFI, 2017).

A szív- és érrendszeri betegek táplálkozási stratégiájában csökkenteni kell az összes zsírbevitelt, a telített zsírsavakat helyettesíteni kell az étrendben telítetlen zsírsavakkal. Csökkenteni szükséges a koleszterinbevitelt, heti gyakorisággal 
kívánatos a halak étrendbe illesztése. A konyhasó fogyasztásának jelentős csökkentése javasolt. A napi étrend gerincét a gabonafélék és az ebből készült élelmiszerek képezzék, valamint a zöldség- és gyümölcsfogyasztásnak el kell érnie a napi $400 \mathrm{~g}$ - ot.

A hazai lakosság kiemelkedő aránya ismeri a cukorbetegség és a szívbetegségek kapcsolatát. A legnagyobb problémát az elhízásra vonatkozó ismeretek hiánya jelenti, a magyar fogyasztók mintegy $30 \%$-a szerint a túlsúlyosság nem okozhat halálos kimenetelü krónikus betegségeket. A felmérésben résztvevők kétharmada $(68,1 \%)$ hisz abban, hogy a táplálkozás jobb módja az egészségvédő tápanyagok bevitelének, mint az étrend-kiegészítők fogyasztása (Szakály, 2009.

\section{Az egészséges táplálkozás szerepe a betegségek megelózésében. A funkcionális élelmiszerek jelentősége.}

Az egészségkockázatokkal kapcsolatos tényezők vizsgálata alapján megállapítható, hogy a hazai egészségveszteségek kockázatai $80 \%$-ban viselkedéssel összefüggő tényezőkre vezethetők vissza. A legnagyobb hangsúlyt képviselők, úgymint az étrendi kockázatok, a dohányzás, az alkohol-és kábítószerfogyasztás mellett kiemelt szerepet játszik az egyén egészségmagatartása is. Az egészségmagatartási mutatók Magyarországra vonatkozó értékei az EU-átlaghoz képest kirívóan rosszak (NEFI, 2017).

Az egészséges táplálkozás feltételezi a megfelelő táplálékválasztást, az ételkészítést, a megfelelő étkezési ritmust és étkezési körülményeket. A legfontosabb azonban az, hogy a táplálék energiatartalma, a tápanyagok minősége, aránya a szervezet igényeinek megfeleljen. A felvett tápanyagok minősége és mennyisége is meghatározó, hiszen szerepük a szervezetben eltérő. A testünk számára szükséges szerves anyagok közül nem vagyunk képesek mindegyiket előállítani, ezeket táplálkozásunk során más élőlények anyagaiból - készen - vesszük fel. Ilyen esszenciális (nélkülözhetetlen) anyagok a telítetlen zsírsavak, egyes aminosavak és a vitaminok. Ha az esszenciális tápanyagok a szükségesnél kisebb mennyiségben kerülnek a szervezetünkbe, ez anyagcserezavarokhoz vezethet, és hiánybetegségek alakulnak ki (Balogh, 2017).

Az utóbbi 25 évben a világon egyre népszerübbé váltak az olyan élelmiszerek, amelyek fogyasztása a nem kiegyensúlyozott táplálkozás okozta vitamin- és ásványianyag-hiányok pótlására, az energiaegyensúly visszaállítására, az egészség és a jó közérzet megőrzésére, illetve egyes betegségek megelőzésére szolgálnak (Babulka, 2005). Az ilyen, egészségvédő hatású élelmiszerek megnevezései nagyon változatosak, leggyakrabban a funkcionális élelmiszer kifejezést használja a szakirodalom. A funkcionális élelmiszer koncepció az 1990-es években kristályosodott ki healthy food, designer food, pharmafood, functional food angol megnevezéssel (Wildman, 2001).

A funkcionális élelmiszerekkel szemben támasztott általános követelmények a következők (Wildman 2001):

- Az élelmiszer javítsa az étrendet és az egészséget, legyen beépíthető a mindennapi táplálkozásba. 
- Az élelmiszer vagy összetevőjének egészségi, táplálkozási hasznossága, illetve a napi ajánlott fogyasztási mennyiség megalapozott tudományos tényeken alapuljon.

- Az élelmiszer legyen biztonságos a kiegyensúlyozott étrend és az élelmiszerbiztonság szempontjából.

- A funkcionális összetevő jellemezhető legyen fizikai és/vagy kémiai tulajdonságokkal, illetve analitikai mérési módszerekkel.

- A funkcionális összetevő ne csökkentse az élelmiszer tápértékét.

- Az élelmiszert szokásos módon lehessen fogyasztani, vagyis ne legyen tabletta, por, kapszula.

- A funkcionális összetevő természetes eredetủ és az emberi szervezet számára hasznosítható formában legyen jelen az élelmiszerben.

A funkcionális élelmiszerek közül a legnagyobb arányban a tejtermékeket, az édességeket, valamint a sütő- és gabonaipari termékeket találjuk meg a kínálatban.

Jasák (2015) tanulmánya megállapítja, hogy a funkcionális élelmiszerek kevésbé elterjedtek a magyar lakosság körében, ugyanis elenyésző azon fogyasztók aránya, akik a mindennapi táplálkozás részeként fogyasztják ezeket a termékeket. Az egészségre gyakorolt kedvező hatás kifejtéséhez azonban javasolt a rendszeres fogyasztásuk, azaz célszerü heti több alkalommal beilleszteni a diétába. Tehát foglalkozni kell azzal a kérdéssel, hogy hogyan növelhető a funkcionális élelmiszerek népszerüsége, vagyis mely tényezők segítségével indukálható magatartásváltozás e téren.

Szakály és Jasák (2014) kutatása arra világított rá, hogy Magyarországon viszonylag alacsony szintü a bizalom a funkcionális élelmiszerekkel kapcsolatban. A bizalmatlanság egyik jele, hogy $40 \%$ azok aránya, akik az egészségvédő élelmiszereknek egészségre káros hatást tulajdonítanak. A magyar fogyasztók nem nagyon hisznek abban sem, hogy egy egészségvédő élelmiszernek ugyanolyan jó íze lehet, mint a hagyományos bolti élelmiszereknek. A felmérésben válaszokat adók mindössze $47 \%$-a érzi úgy, hogy a funkcionális élelmiszerek fogyasztása elönyös számukra, a többség álláspontja erősen megosztott ebben a kérdésben. Mivel hiányoznak a „kiforrott” attitüdök, ezért a tudatos magatartás csak szük körben jellemző a hazai fogyasztókra. Ebbe a csoportba jellemzően a nők, a magasabb iskolai végzettségü és jövedelmü háztartások, az aktív szellemi tevékenységet végzők, valamint az elsődleges élelmiszer-beszerzők sorolhatók.

Szakály (2017) arra hívja fel a figyelmet, hogy a táplálkozásmarketingtevékenység során erősíteni kell a bizalmat az egészségvédő funkcionális élelmiszerek iránt. Közérthetően kell bemutatni azokat a fontos egészségre ható elönyöket, amelyek a funkcionális élelmiszerek fogyasztásából származnak. Temesi és Hajtó (2014) szintén azt állapította meg, hogy a funkcionális élelmiszerek is bizonyos tekintetben bizalmi termékek, a fogyasztók vásárlásaik során csak szakemberekre (orvosok, dietetikusok), közeli személyekre (barátok, családtagok) vagy széleskörü információgyüjtésre (internet, fogyasztóvédelmi hatóság információi) támaszkodnának. 


\section{4. Összegző gondolatok}

A magyar lakosság mindössze $14 \%$-a tekinthető egészségtudatosnak, akik ismerik és tudatosan választják azon élelmiszereket, amelyek egészségvédő tulajdonságokkal rendelkeznek. Annak ellenére, hogy a fogyasztók szeretnék a betegségeket elkerülni, a többség mégsem hajlandó ezért anyagi áldozatot hozni. Jellemzően egy-egy tudott betegség sem aggasztja a fogyasztókat olyan mértékben, hogy azon változtatna a mindennapi életben, és azok elkerülést kínáló termékeket részesítené előnyben. Sajnos sok esetben az utólagos kezelésben bíznak és nem a megelözésre helyezik a hangsúlyt.

Napjaink felgyorsult világában, az időhiány miatt gyakran olyan ételeket esznek az emberek, amelyeknek a rendszeres fogyasztása egészségtelen. A helytelen táplálkozás miatt súlyos problémaként jelentkezik az elhízás, melynek következtében a zsír lerakódik az érfalakon, érszükület alakul ki. Erre a szervezet a vérnyomás emelkedésével reagál, amely megnöveli az agyvérzés és az infarktus kialakulásának kockázatát. Az elhízottság olyan betegség, amely számos más betegségek előzménye is lehet. Sajnos a kockázatokat tovább növeli a mozgásszegény életmód is. A mindennapok megváltozott életkörülményeihez ki kell alakítani a megfelelő táplálkozási és életmódbeli szokásokat. A civilizációs betegségek leküzdéséhez és kezeléséhez sokkal erőteljesebben kell tudatosítani az emberekben a megváltozott körülmények emberi szervezetre gyakorolt hatásait.

\section{Irodalomjegyzék}

Antal E (2007): Civilizációs betegségek: Mit tehetünk ellenük? Élelmiszer, táplálkozás és marketing. IV.évf. (1) 37-39.

Babulka P. (2005): Gyógyhatású táplálékok, étrend-kiegészítők, funkcionális élelmiszerek és betegségmegelőző anyagok. Komplementer Medicina 9 (3) 58-66.

Balogh S. (2017): Alternatív táplálkozás - választható táplálékaink. Oriold és Társai Kiadó, Budapest Després J. P. (2001): Health consequences of visceral obesity. Annals of medicine 33. 534-541.

Jasák H. (2015): Funkcionális élelmiszerek fogyasztását befolyásoló attitűdök vizsgálata. Journal of Central European Green Innovation 3 (3) 95-112.

Mózsik Gy.-Figler M.-Vincze Á.-Szakály S.-Széles Gy.: Actualities of the nutritional state of Hungary. Az integrált élelmiszergazdaság biológiai és gazdasági alapjainak feltárása a DélDunántúlon. PATE, Kaposvár, 1992, 17-35.

NEFI (2017): Egészségjelentés 2016. Információk a népegészségügyi beavatkozások célterületeinek azonosításához a nem fertőző betegségek és az egészségmagatartási mutatók elemzése alapján. Nemzeti Egészségfejlesztési Intézet, Budapest, 2017.

Popkin. B. : The world is fat. The fads, trends, policies and products that are fattening the human race. Avery, New York, 2009.

Povey. R.- Conner.M.-Sparks. P.-James. R.-Shepherd. R.: Interpretations of Healthy and Unhealthy Eating, and Implications for Dietary Change. Health Education Research. 1998.(13) 171-183.

Puska P.-Waxman A.-Porter D. : The global strategy on diet, physical activity and health. World Health Organization, Geneva, 2003

Soós P.- Szelid Zs.-Bagyura Zs.-Merkely B.: A szív és érrendszeri megbetegedések magyarországi epidemiológiája. www.semmelweis-kutatoegyetem.hu

Szakály Z. (2009): Egészségmagatartás és funkcionális élelmiszerek: Hogyan vélekednek a magyar fogyasztók? Élelmiszer Táplálkozás és Marketing VI. évf. (1-2) 9-18.

Szakály Z. (2011): Táplálkozás-marketing. Mezőgazda Kiadó, Budapest

Szakály Z (2017): Élelmiszer-marketing. Akadémiai Kiadó, Budapest 
Szakály Z. - Jasák H. (2014): A fogyasztók egészségmagatartása. 500 fős országos reprezentatív kérdöíves lakossági felmérés, Debreceni Egyetem

Szücs Zs (2016): OKOSTÁNYÉR- új táplálkozási ajánlás a hazai felnőtt lakosság számára. Egészségfejlesztés 57 (4), 68-70.

Temesi Á.- Hajtó J. (2014): Funkcionális élelmiszerek termékfejlesztésének alapjai- fogyasztói magatartáskutatás. Élelmiszer, táplálkozás és marketing X. (1) 11-20.

Wildman R. E. C.: Handbook of neutraceuticals and functional foods. CRC Press, Boca Raton, FL, 2001

European Food and Nutrition Action Plan 2015-2020. www.euro.who.int/data/assets/pdf_file0008/253727/64wd04e_FoodnutAP140426pdf

Európai Bizottság Táplálkozás és Testmozgás Szakpolitika. www.ec.eurpa.eu/health/nutrition_physical activity/policy/index.hu

Strategy for Europe on nutrition, overweight and obesity related health issues (2010). www.ec.europe.eu/health/nutrition_physical acttivity/docs/implementation report.en.pdf

Országos Táplálkozás és Tápláltsági Állapot Vizsgálat 2009. www.oeti.hu/m1id=16m2id=169 